\title{
フェムト秒時間分解第 2 高調波発生による 表面吸着種の振動ダイナミクス
}

\author{
渡邊 一也・松本 吉泰 \\ 自然科学研究機構分子科学研究所分子スケールナノサイエンスセンター \\ 傿 444-8585 愛知県岡崎市明大寺町字西郷中 38 \\ (2005 年 6 月 30 日受理)
}

\section{Vibrational Dynamics of Surface Adsorbates Studied by Femtosecond Time-resolved Second Harmonic Generation}

Kazuya Watanabe and Yoshiyasu Matsumoto

Research Center for Molecular-scale Nanoscience, Institute for Molecular Science 38 Nishigonaka, Myodaiji, Okazaki, Aichi 444-8585

(Received June 30, 2005)

In this paper, we focus on our recent study on vibrational coherence and coherent phonon of Cs or K adsorbed on Pt (111) by using femtosecond time-resolved second harmonic generation. The dynamics of vibrational coherence of alkali-Pt stretching mode is observed in time-domain and the mechanism of vibrational dephasing is discussed. We also study an effect of pulse shaping on a mode-selective coherence excitation.

\section{1. は じめ に}

近年, 超短パルスレーザー技術の進展と共に, 固体表 面でのフェムト秒〜ピコ秒スケールの超高速ダイナミク スに関する知見が得られるようになってきた。電子励起 状態の緩和過程については, 主に時間分解 2 光子光電子 分光法を用いて ${ }^{1)}$, また, 吸着種の振動ダイナミクスに 関しては, 短パルスレーザーを光源とした, 赤外ポンプー プローブ測定や時間分解可視-赤外和周波発生振動分光 による研究が行われている2。これらの時間分解測定は, ほとんどが電子状態や振動状態の占有数の緩和を対象と したものである。

一方, レーザーを用いた化学反応の制御を考える場合, レーザー光により誘起されるコヒーレンスに関する知見 が重要であり ${ }^{3)}$, 特に, 表面吸着種の化学結合に関連の 深い振動波束（振動コヒーレンス）の生成・消失過程に 興味がもたれる。気相・溶液中やバルク固体中などの他 の相での振動波束ダイナミクス（コヒーレントフォノン） 研究は目覚しい進展を見せているにもかかわらず4,5),

E-mail: matsumoto@ims.ac.jp
表面吸着種を対象とする研究はこれまで報告がなく, 測 定手法自体が確立されていなかった。また, 液晶変調素 子等を用いた超短パルスレーザー光の波形変調により, 化学反応を制御しようという研究が活発に行われ ${ }^{3)}$, 気 相や溶液中の分子については解離6)や異性化反応7)の選 択性や効率をある程度制御できることが実証されている が, 表面吸着種に対しレーザーパルス波形制御の効果を 調べた例はないのが現状である。

著者らは最近, 清浄金属表面に吸着したアルカリ原子 層について, フェムト秒時間分解第 2 高調波測定 (Timeresolved second harmonic generation, TRSHG）による吸着 種の振動波束ダイナミクス (コヒーレント表面フォノン) の観測に成功した ${ }^{8 \sim 11)}$ 。本稿では, 我々の研究成果を中 心に, 表面吸着種の振動波束ダイナミクスについて解説 する。

\section{TRSHG による表面振動コヒーレンスの観測}

一般に，特定の振動モードの振動周期より短い時間幅 のレーザーパルスを用いて物質を励起すると, 異なる振 動量子準位の重ね合わせ状態（振動波束）が生成する。 問題とする基準振動座標の期待值 $\langle Q\rangle$ は, 振動のエネ 
ルギー固有状態では，振動の平衡位置になるが，異なる 振動量子数の重ね合わせ状態では, 古典的な運動方程式 と同様な次式に従うことが示される12)。

$$
\frac{d^{2}\langle Q\rangle}{d t^{2}}+\frac{2}{T_{2}} \frac{d\langle Q\rangle}{d t}+\Omega^{2}\langle Q\rangle=F
$$

ここで $T_{2}$ は位相緩和時間， $\Omega^{2}=\omega^{2}+T_{2}{ }^{-2}$ である。ま た $F$ は光との相互作用により印加される力であり, 励起 がラマン過程で起こる場合は, $\alpha$ をラマンテンソル, $E$ を励起光電場ベクトルとして $F \propto \alpha: E E$ となる。励起 光の時間幅が十分短く $F$ を $\delta$ 関数とみなせる場合, (1) 式は時定数 $T_{2}$ で振幅が指数関数的に減衰する正弦波型 の解を与える。

通常, 溶液中の分子や固体に対するポンプ・プローブ 測定では, $\langle Q\rangle$ に依存した感受率の変調成分を検出す る。表面吸着種の場合, 測定対象となる原子・分子数が バルクの測定に比して圧倒的に少ないために, 通常のポ ンプ・プローブ測定手法では検出に困難が伴う。Tom らのグループは GaAs 清浄表面を対象として, 表面敏感 な第 2 高調波発生（SHG）強度をモニターすることで, 表面の振動モードの時間領域観測が可能になることをは じめて示した ${ }^{13)}$ 。我々は, この手法をアルカリ単原子層 吸着金属表面に適用し, 単層吸着種の振動の実時間観測 が可能であることを見出した。以下にその測定原理を簡 単に述べる。

超高真空中で固体表面にポンプとプローブ 2 つのフェ ムト秒パルスを照射し，プローブ光と同軸に発生する SHG 強度をポンプープローブの遅延時間の関数として測 定する。SHG の源となる非線形感受率を $\chi_{n l}$ とし， $\chi_{n l}$ をポンプにより変調を受ける成分 $d \chi_{n l}$, およびポンプ に依存しない成分 $\chi_{n l 0}$ に分けられると仮定すると, 実 際に観測される SHG 強度, $I_{2 w}$ は

$$
I_{2 w} \propto\left|\chi_{n l}\right|^{2}=\left|\chi_{n l 0}\right|^{2}+\left|d \chi_{n l}\right|^{2}+2 \cdot \operatorname{Re}\left\{\chi_{n l 0} \cdot d \chi_{n l}\right\}
$$

で与えられる。通常 $d \chi_{n l}<<\chi_{n l 0}$ であるのでポンプープ ローブ遅延時間に依存した SHG 強度変化は（2）式の第 3 項で与えられ $d \chi_{n l}$ に比例する。 $d \chi_{n l}$ のうち $\langle Q\rangle$ に 依存する成分を $d \chi_{n l}(Q)$ と書くと, coherent amplitude が小さい条件下では $d \chi_{n l}(Q) \propto\langle Q\rangle$ と近似でき, SHG 強度が（1）式に従う減衰振動的な時間変化を示すこと がわかる14)。

$d \chi_{n l}$ には系の電子励起に伴う変調成分も含まれるた め, TRSHG 信号には上に述べた核変位による成分に加 え電子励起状態の緩和過程を反映した減衰成分も観測さ れる。

SH 光が表面敏感な信号を含むことは良く知られてい るが, 加えて, 本稿で解説するアルカリ吸着表面の場合,
アルカリ吸着由来の表面局在電子状態間遷移への共鳴 ${ }^{15)}$ (あるいは表面プラズモン共鳴に近づくこと16) $)$ にり, SH 光強度の著しい増大が起き，これが表面単層吸着種 の観測を可能にしている。

\section{3. アルカリ吸着金属表面での振動波束ダイ ナミクス}

Fig. 1 に $\mathrm{Pt}(111)$ 表面に K を蒸着した系での TRSHG 信号の被覆率 $(\theta)$ 依存性を示す 11$)$ 。すべての実験は同 一の超高真空チェンバー内 $\left(2 \times 10^{-10}\right.$ Torr 以下 $)$ で, $\mathrm{Pt}$ （111）清浄表面にアルカリ原子を蒸着して行った。試料 温度は $110 \mathrm{~K}$ である。測定用の光源は $\mathrm{Ti}$ : sapphire レー ザーの再生増幅光 (パルス幅 $150 \mathrm{fs}$, 中心波長 $800 \mathrm{~nm}$ ), あるいはこれをべースにした非同軸パラメトリック増幅 器（パルス幅約 $25 \mathrm{fs}$ ，中心波長 $580 \mathrm{~nm}$ ）を用いた ${ }^{10)}$ 。

$\operatorname{Pt}$ (111) 清浄表面で観測される過渡応答は, レーザー 照射による $\mathrm{Pt}$ 基板電子の励起, 熱緩和過程を反映した ものである。 $1 \mathrm{ps}$ 以内に観測される減衰成分は，主に電 子-格子相互作用による緩和と考えられ，ここではイン コヒーレントなフォノンの励起が起きている。

$\theta=0.22 \mathrm{ML}$ （1 ML は Pt(111）清浄表面の原子密度, $\left.1.5 \times 10^{15} \mathrm{~cm}^{-2}\right)$ の $\mathrm{K}$ 原子を吸着すると，清浄表面の信 号に酷似した時間変化を示すバックグラウンド成分と弱 い振動成分が観測される。バックグラウンド成分の符号 はマイナス側に現れる。これは，K原子吸着により引き 起こされる $\chi_{n l}$ の変化分の位相が清浄表面の $\chi_{n l}$ の位相 と異なっているためと考えられる。

さらに被覆率を上げると, 振動成分の寄与は増大する。

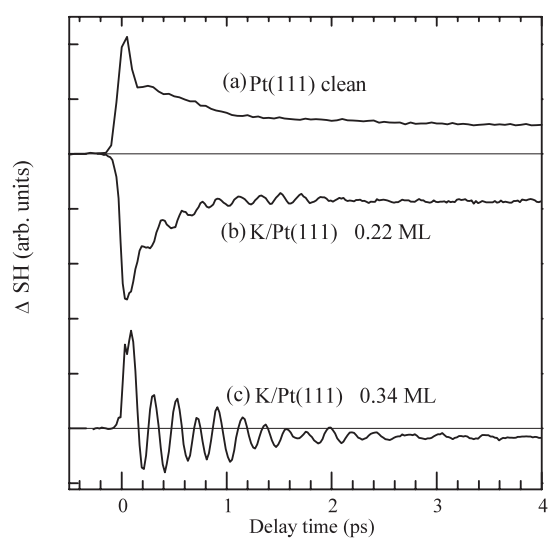

Fig. 1. Typical TRSHG traces taken from $\mathrm{K} / \mathrm{Pt}(111)$ for (a) $\theta=0 \mathrm{ML}$ (Pt(111) clean surface), (b) $\theta=0.22 \mathrm{ML}$, and (c) $\theta=0.34 \mathrm{ML}$, respectively. The excitation wavelength was $580 \mathrm{~nm}$. Sample temperature was held at $110 \mathrm{~K}$ during the measurement. The zero for each trace is indicated by the upper thin line for (a) and (b), and by the lower thin line for (c). 
Fig. 2 には, 振動部分のフーリエスペクトルの被覆率依 存性を示した。4.5〜 $5.2 \mathrm{THz}$ に現れる顕著なピークは HREELS で観測されている K-Pt の伸縮振動数に一致 し17)，吸着種-基板間の振動コヒーレンスが誘起されて いることがわかる。これは, 表面上に多数存在する K-Pt ボンドが位相を揃えて振動していることに対応する。同 様の信号は Cs/Pt (111) についても観測され, Cs-Pt 伸 縮振動に対応する振動成分が確認されている ${ }^{8 \sim 10)}$ 。

Fig. 2 で, K-Pt 伸縮振動領域のピークは被覆率に応じ てその中心周波数がシフトあるいは分裂する。 $\theta=0.22$ ML 付近では, $5.3 \mathrm{THz}$ のピークが顕著に表れ, 被覆率 の増大と共に $4.6 \mathrm{THz}$ 付近のピークが成長し, $\theta=0.34$ ML 以上では $4.8 \mathrm{THz}$ のピークとなる。Pirug らの LEED による研究では ${ }^{18)}, 0.20 \mathrm{ML}$ から $0.33 \mathrm{ML}$ にかけて $2 \times 2$ 構造から $\sqrt{3} \times \sqrt{3}$ 構造へ吸着種構造が変化するとされて おり, 低被覆率領域で顕著な $5.3 \mathrm{THz}$ の成分は $\mathrm{K} / \mathrm{Pt}$ (111)-(2×2) ドメインからの信号, $4.6 \mathrm{THz}$ のピークは $(\sqrt{3} \times \sqrt{3})$ ドメインからの信号と考えられる。

また，2.6〜2.9 THzに中心周波数をもつ成分が観測さ れるが，これは，Cs 吸着 Pt(111）でも観測され, Pt 清 浄表面で表面フォノン（Rayleigh フォノン）のブリルア ンゾーン境界でのモードが, 吸着原子が周期構造をとる ために $\Gamma$ 点に折り返され，励起されたと考えられる10)。

振動コヒーレンスの誘起される機構としてはアルカリ 吸着誘起の表面電子準位間の電子遷移に共鳴したインパ ルシブラマン散乱過程が考えられる。アルカリ原子由来 の非占有軌道に遷移した電子の位相緩和時間や占有数の

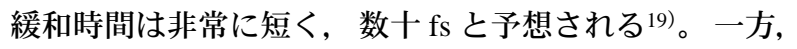
TRSHG で観測された吸着種一基板間振動コヒーレンス は $1 \mathrm{ps}$ 以上の位相緩和時間を有し, 明らかに電子励起 状態の寿命より長い。したがって, 観測された振動波束

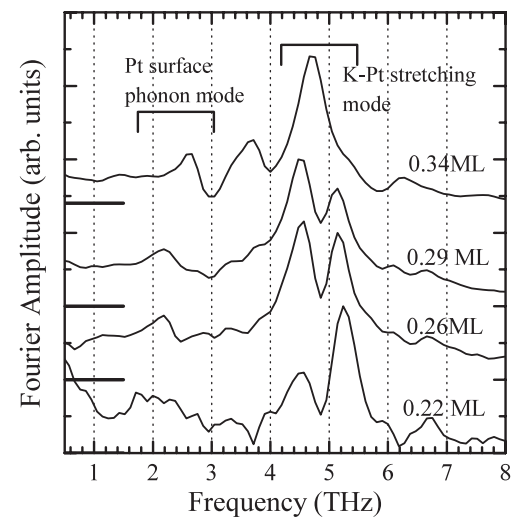

Fig. 2. Fourier amplitude spectra of oscillatory components observed in TRSHG traces on $\mathrm{K} / \mathrm{Pt}(111)$ as a function of $\mathrm{K}$ coverage. Each spectrum is normalized at their peaks. $\mathrm{K}$ coverage is indicated in the figure.
ダイナミクスは表面の非占有準位に励起された電子が緩 和した後の現象を見ていることになる。

\section{4. 吸着種の振動位相緩和過程}

金属表面吸着種の振動位相緩和過程は，これまで主に 反射赤外吸収スペクトルの形状から議論されてきた ${ }^{20)}$ 。 位相緩和の機構としては，エネルギー緩和過程と純粋位 相緩和過程とに区別され，前者は個々の振動子の振幅が 減衰していく過程, 後者ははじめ振動位相が揃っていた ボンド間で時間と共に相対位相がずれていく過程を指 す。エネルギー緩和としては基板の電子-正孔対励起に よる緩和や21), 基板の格子振動励起によるエネルギー緩 和が考えられる22)。純粋位相緩和過程では, 他の振動モ ードとの非調和結合による位相緩和が重要である23)。

TRSHG で観測されたアルカリ-Pt 伸縮振動モードの 場合, その振動数が Pt バルクフォノンの最大周波数に 比べて低いため, 基板フォノン励起による緩和が考えら れる。また強い化学吸着系であるため, 核の変位により 基板一吸着種間の電荷移動が引き起こされ，電子-正孔対 励起によるエネルギー緩和も大きく寄与するであろう。

Fig. 3 に Cs/Pt（111） における Cs-Pt 伸縮振動の位相緩 和時間の被覆率依存性を示す10)。 $\theta=0.36 \mathrm{ML}$ までは, 被覆率の増大と共に位相緩和時間はほぼ単調減少し, $0.36 \mathrm{ML}$ 付近で $0.5 \mathrm{ps}$ 程度になるが，ほぼ 1 層目が完結 する $0.40 \mathrm{ML}$ 付近で $1.5 \mathrm{ps}$ 程度に増大する。基板フォノ ン励起による緩和の場合, elastic continuum model によ れば位相緩和時間は表面原子密度に反比例して変化する と予測されており ${ }^{22)}, \theta=0.36 \mathrm{ML}$ までに観測される位 相緩和時間の減少は定性的にはこれで説明される。1 層 完結時に引き起こされる位相緩和時間の増大は，この近 傍での Cs 吸着層の構造変化に起因していると考えられ

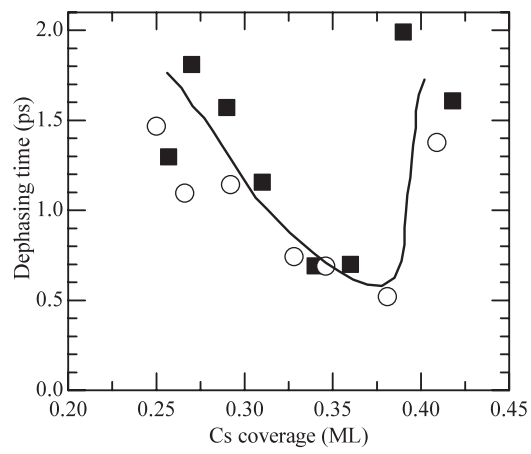

Fig. 3. Coverage dependence of vibrational dephasing time of Cs-Pt stretching mode on $\mathrm{Cs} / \mathrm{Pt}(111)$. Filled squares: $580 \mathrm{~nm}$ excitation. Open circles: $800 \mathrm{~nm}$ excitation. Sample temperature was $110 \mathrm{~K}$. Typical errors for the estimated dephasing time were $\pm 10 \%$. The solid curve is a guide to eye. 
る。すなわち, $0.40 \mathrm{ML}$ 付近では Cs 構造が下地に不整 合となるため, 格子不整合により長波長表面フォノンへ のエネルギー緩和の効率が低くなる22)。

また，詳細は文献に譲るが，Cs-Pt 伸縮振動の位相緩 和時間の温度依存性を調べた結果, 表面平行方向の振動 モードとの非調和結合による純粋位相緩和過程が支配的 になることがわかった ${ }^{10)}$ 。さらに, 高強度レーザー光を 照射したことにより引き起こされる特有の位相緩和過程 も見出された9)。

\section{5. フェムト秒パルス列によるモード選択励起}

これまで, 一旦誘起されたコヒーレンスが消失して行 く過程について述べてきたが, より積極的に核波束のダ イナミクスを制御し, 特定の反応誘起に結びつけること は可能であろうか。このような試みの第 1 歩として, 波 形変調パルスを用いて, コヒーレントフォノンをモード 選択的に励起することが考えられる。

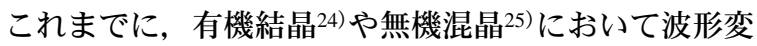
調パルスによるモード選択励起が報告されているが, 固 体表面のモードを対象にした実験は行われていなかっ た。

我々は, 特定の周期をもつフェムト秒パルス列を用い
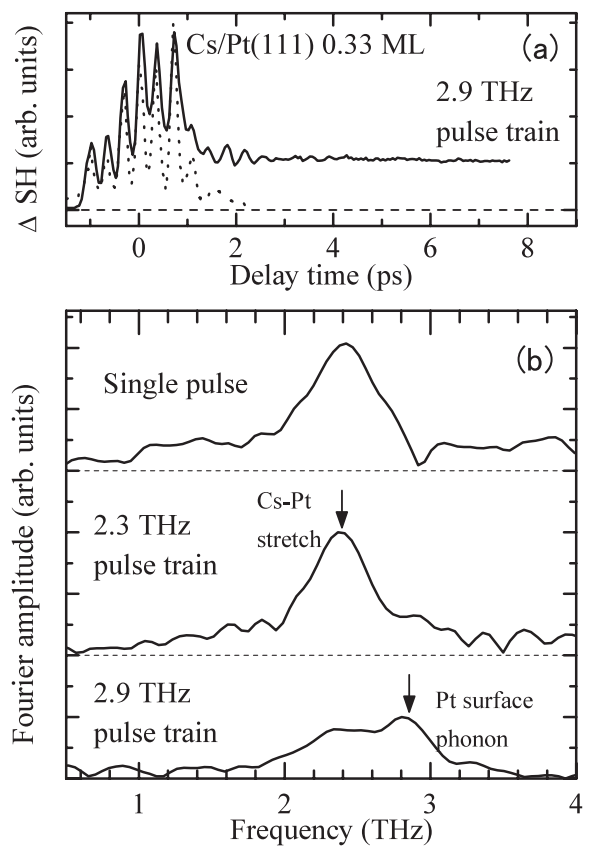

Fig. 4. (a) Solid line: A TRSHG trace from $0.33 \mathrm{ML} \mathrm{Cs} / \mathrm{Pt}$ (111) by $2.9 \mathrm{THz}$-rate pulse train excitation. Dashed curve: a cross-correlation trace of $2.9 \mathrm{THz}$-rate pulse train. (b) Fourier amplitude spectra of oscillatory components in TRSHG traces of $0.33 \mathrm{ML} \mathrm{Cs} / \mathrm{Pt}$ (111). Top trace: single pulse excitation. Middle trace: $2.3 \mathrm{THz}$-rate pulse train excitation. Bottom trace: $2.9 \mathrm{THz}$-rate pulse train excitation.
て表面振動コヒーレンスのモード選択励起を試みた ${ }^{26)}$ 。 Fig. 4 に Ti : sapphire レーザーの基本波（150 fs，800 nm） を液晶変調素子によりパルス列に変換した励起光による $\mathrm{Cs} / \mathrm{Pt}-(\sqrt{3} \times \sqrt{3})$ 表面での TRSHG 测定結果を示す。パ ルス列周期を Cs-Pt 伸縮振動（2.3 THz）に一致させた場 合，Cs-Pt 伸縮振動が選択的に励起され，それより高い $2.9 \mathrm{THz}$ に設定した場合, Cs-Pt 伸縮振動モードのピーク は抑制され，かわりに Pt 表面フォノンに帰属される 2.9 $\mathrm{THz}$ の成分が顕著に観測される。波形変調しない単一 のフェムト秒パルスを用いて励起した場合と比較して, パルス列励起を用いることで, 表面フォノン信号の Cs$\mathrm{Pt}$ 伸縮振動モードに対する初期振幅の比は約 4 倍増強 することがわかった。

\section{6. おわりに}

本稿では, TRSHG による表面吸着種の振動波束ダイ ナミクス研究の現状について, 我々の研究成果を中心に 解説した。今後, 表面化学の観点から興味の持たれる吸 着酸素原子や水素原子などについて，その核波束ダイナ ミクス・振動励起ダイナミクス観測を目指す段階に来て いる。吸着種由来の電子状態間遷移への共鳴条件が満た されるためには, 紫外域の短パルスレーザー光を用いる 必要があると考えられる。

また，レーザー波形変調による，表面ダイナミクスの 制御が興味の持たれるところである。遺伝的アルゴリズ ムによる最適波形探索を表面光化学反応に適用するのが 効率的と考えられるが，表面反応の場合，均一系と異な り反応生成物の堆積効果が feedback loop の構築の障害 となり，この分野での進展を妨げている。この問題が解 決されれば，光による表面反応制御の新たな局面を迎え るものと期待される。得られた最適化波形による反応過 程を理解するためには，本稿で述べた時間分解測定手法 を用いた核波束ダイナミクスの直接観測が有効となると 考えられる。

\section{謝 辞}

本稿の内容は, 高木紀明氏（現東京大学大学院創成科 学研究科）との共同研究の成果である。ここに改めて感 謝する。

\section{文献}

1) P.M. Echenique, R. Berndt, E.V. Chulkov, Th. Fauster, A. Goldmann and U. Höfer: Surf. Sci. Rep. 52, 219 (2004).

2) H. Ueba: Prog. Surf. Sci. 55, 115 (1997).

3) M. Dantus and V.V. Lozovoy: Chem. Rev. 104, 1813 (2004). 
4) 田原太平 : 分光研究 47, 37 (1998).

5) T. Dekorsy, G.C. Cho and H. Kurz: "Light Scattering in Solids VIII", ed. By M. Cardona and G. Güntherodt (Springer, Berlin, 2000) p. 169.

6) A. Assion, T. Baumert, M. Bergt, T. Brixner, B. Kiefer, V. Seyfried, M. Strehle and G. Gerber: Science 282, 919 (1998).

7) G. Vogt, G. Krampert, P. Niklaus, P. Nuernberger and G. Gerber: Phys. Rev. Lett. 94, 068305 (2005).

8) K. Watanabe, N. Takagi and Y. Matsumoto: Chem. Phys. Lett. 366, 606 (2002).

9) K. Watanabe, N. Takagi and Y. Matsumoto: Phys. Rev. Lett. 92, 057401 (2004).

10) K. Watanabe, N. Takagi and Y. Matsumoto: Phys. Rev. B 71, 085414 (2005).

11) K. Watanabe, N. Takagi and Y. Matsumoto: "Ultrafast Phenomena XIV" (Springer, Berlin, 2005) p. 307.

12) M.D. Levenson and S.S. Kano: "Introduction to Nonlinear Laser Spectroscopy", Revised Edition (Academic Press, London, 1987) p. 132.

13) Y.M. Chang, L. Xu and H.K.W. Tom: Phys. Rev. Lett. 78, 4649 (1997).

14) Y.M. Chang, L. Xu and H.W.K. Tom: Chem. Phys. 251,
283 (2000).

15) H.W.K. Tom, C.M. Mate, X.D. Zhu, J.E. Crowell, Y.R. Shen and G.A. Somorjai: Surf. Sci. 172, 466 (1986).

16) S.A. Lindgren and L. Walldén: Phys. Rev. B 45, 6345 (1992).

17) C. Klünker, C. Steimer, J.B. Hannon, M. Giesen and H. Ibach: Surf. Sci. 420, 25 (1999).

18) G. Pirug and H.P. Bonzel: Surf. Sci. 194, 159 (1988).

19) S. Ogawa, H. Nagano and H. Petek: Phys. Rev. Lett. 82, 1931 (1999)

20) H. Ueba: Prog. Surf. Sci. 22, 181 (1986).

21) B.N.J. Persson and M. Persson: Solid State Commun. 36, 175 (1980).

22) B.N.J. Persson, E. Tosatti, D. Fuhrmann, G. Witte and Ch. Wöll: Phys. Rev. B 59, 11777 (1999).

23) B.N.J. Persson and R. Ryberg: Phys. Rev. B 32, 3586 (1985).

24) A.M. Weiner, D.E. Leaird, G.P. Wiederrecht and K.A. Nelson: Science 247, 1317 (1990).

25) M. Hase, T. Itano, K. Mizoguchi and S. Nakashima: Jpn. J. Appl. Phys. Part 2, 37, L 281 (1998).

26) K. Watanabe, N. Takagi and Y. Matsumoto: Phys. Chem. Chem. Phys. 7, 2685 (2005). 